\title{
A Case of Invasive Mole
}

\author{
S Ahmed ${ }^{1}$, DR Shaha ${ }^{2}$
}

\begin{abstract}
:
Invasive mole is a condition where a molar pregnancy, such as a partial hydatidiform mole or complete hydatidiform mole, invades the wall of the uterus, potentially spreading and metastasizing to other parts of the body. Here is a case who presented with history of evacuation for molar pregnancy. She presented with irregular P/V bleeding on and off and after admission silent perforation with massive haemoperitoneum was detected for which emergency laparotomy was done. She recovered and was followed up till her $\beta$-hCG levels were within normal limits. As patient presented to us with haemoperitoneum and on laparotomy, there was invasion into whole of the uterus, it could not be saved and hysterectomy was done.
\end{abstract}

Key words: Invasive mole, Molar pregnancy.

\section{Introduction:}

Invasive mole is a condition where a molar pregnancy such as a partial hydatidiform mole or complete hydatidiform mole invades the wall of uterus, potentially spreading and metastasizing to other parts of the body (such as vagina or lungs) ${ }^{1}$. Invasive mole occurs in about $20 \%$ of molar pregnancies but are more common in complete molar pregnancies than in partial molar pregnancies ${ }^{2-4}$. Invasive moles can develop both before and after treatment by Dilatation, Evacuation \& Curettage (D, E \& C $)^{5}$. Treatment of an invasive mole may include chemotherapy ${ }^{6}$.

\section{Case report:}

Mrs. Humaira, 25 years old, housewife of a middle class family hailing from Boalmari, Faridpur got herself admitted in Diabetic Association Medical College Hospital with the complaints of severe lower abdominal pain and vomiting for 1 day with $\mathrm{H} / \mathrm{O}$ fainting attack and $\mathrm{P} / \mathrm{V}$ bleeding for few days and $\mathrm{H} / \mathrm{O}$ suction, evacuation and curettage for molar pregnancy 4 months back. After admission her emergency USG of whole abdomen was done and revealed mixed echoic materials associated with huge collection in peritoneal

1. Dr. Shahana Ahmed, FCPS (Obst and Gynae), Assistant Professor,
Department of Obstetrics and Gynaecology, Diabetic Association Medical College, Faridpur.

2. Prof. Dr. Dipti Rani Shaha, FCPS (Obst and Gynae), Professor \& Head, Department of Obstetrics and Gynaecology, Diabetic Association Medical College, Faridpur.

Address of correspondence :

Dr. Shahana Ahmed, FCPS (Obst and Gynae), Assistant Professor,

Department of Obstetrics and Gynaecology, Diabetic Association

Medical College, Faridpur. Mobile: +8801714105201,

Email: dr.shamolee42rme@gmail.com cavity. Her general condition was deteriorating and emergency laparotomy was done within 2 hours of her admission.

After opening of abdomen there was huge peritoneal collection with clotted blood. Uterus was perforated in multiple sites by invasive mole and bleeding was present in all the perforating sites. Total abdominal hysterectomy was done with conservation of both ovaries. After counting mops and instruments abdomen was closed in layers. Her chest X-ray revealed no metastasis. She gave $\mathrm{H} / \mathrm{O}$ suction, evacuation and curettage for molar pregnancy 4 months back. At that time she presented with 8 weeks amenorrhea which was confirmed by strip test with irregular P/V bleeding. Her USG report revealed hydatidiform mole. Her pre evacuation serum $\beta$-hCG was $>5000 \mathrm{mIU} / \mathrm{ml}$. After evacuation endometrial histopathology revealed hydatidiform mole with no evidence of malignancy. 1 week after evacuation serum $\beta$-hcg was $2151 \mathrm{mIU} / \mathrm{ml}$. Patient was advised to come 2 weeks later with report of serum $\beta$-hCG but she did not come. Regarding her obstetric history she was married for 7 years, mother of 2 babies. All were normal vaginal delivery. Age of her last child was 5 years. Histopathology confirmed the diagnosis of an invasive mole. As patient presented to us with haemoperitoneum and there were multiple perforations in whole of the uterus, hysterectomy was done.

\section{Discussion:}

Gestational trophoblastic neoplasia (GTN) arises when the normal regulatory mechanism controlling the proliferation and invasiveness of trophoblastic tissue are lost. These are rare and constitute less than $1 \%$ of 
all gynecologic malignancy. They are characterized by a distinct tumor marker $\beta-\mathrm{hCG}$ and have varying tendencies toward local invasion and distant metastasis $^{5}$. Vascular invasion and metastasis rarely occur in invasive mole ${ }^{6}$. Demonstration of myometrial vascular mass without the evidence of fetal material on USG in the context of an elevated $\beta$-hCG is highly suggestive of $\mathrm{GTN}^{7-10}$. An invasive hydatidiform mole is a form of GTN that occurs due to abnormal proliferation of placental trophoblast ${ }^{11}$.

It most commonly occurs after the evacuation of Gestational trophoblastic disease (GTD). It is characterized by the presence of edematous chorionic villi with trophoblastic proliferation that invades into the myometrium of the uterus or to adjacent structures such as the vagina, vulva, broad ligament and can also invade into the uterine vessels ${ }^{12}$. Invasive mole is unlike choriocarcinoma, where chorionic villi pattern is lost. It is important to distinguish between invasive mole and choriocarcinoma as the former has a more favorable outcome ${ }^{13}$.

The clinical presentation of an invasive mole includes vaginal bleeding, an enlarged uterus and high urinary or serum $\beta$-hCG level, typically after the evacuation of a molar pregnancy. The interval from an antecedent molar pregnancy is usually less than 6 months $^{12}$. Choriocarcinoma can occur after a hydatidiform mole or even after a normal pregnancy with an interval of more than 6 months, sometimes nearly 10 years. $\beta$-hCG levels are much higher in choriocarcinoma than invasive mole ${ }^{12}$. Approximately $8 \%$ of patients with complete moles will develop a malignant tumor after evacuation $^{11}$. Therefore, serial values of $\beta$-hCG should be obtained after evacuation, which if presently elevated, should raise the suspicion of $\mathrm{GTN}^{13}$.

\section{Conclusion:}

Malignant GTN can develop as invasive mole, choriocarcinoma and placental site trophoblastic tumor. Ovarian theca luteal cysts usually follow malignant GTN. Early diagnosis and treatment according to accepted protocols could preserve reproductive health in patient with malignant GTN. Serum chorionic gonadotrophine is of a great value for early diagnosis as well as in follow up the effects of treatment.

\section{References :}

1. Moodley M, Tunkyi K. Gestational trophoblastic syndrome an audit of 112 patients. Int J Gynecol Cancer 2003; 13(2):234-9.

2. I lancheran A. Optimal treatment in gestational trophoblastic disease. Ann Acad Med Singapore 1998; 27:698-704.

3. Palmer JR. Advances in the epidemiology of gestational trophoblastic disease. J Reprod Med 1994; 39:155-62.

4. Prameela Mohsina Iffath S. Unusual presentation of molar pregnancy - a case report. J Evol Med Dent Sci. 2014; 8:2073-5.

5. El-agwany AS. Uterine intramural persistent mole: a case report following molar pregnancy evacuation with arteriovenous malformation. Egypt J Radiol Nucl Med. 2014; 45(4):1291-4.

6. Soper JT, Mutch DG, Schink JC. American College of Obstetricians and Gynecologists. Diagnosis and treatment of gestational trophoblastic disease: ACOG Practice Bulletin No. 53. Gynecol Oncol. 2004; 93:575-85.

7. Maeda K, Kurjak A, Varga G, Honemeyer U. Trophoblastic diseases. Donald School J Ultrasound Obstet Gynecol. 2012; 6:27-42.

8. Martonffy AI, Rindfleisch K, Lozeau AM, Potter B. First trimester complications. Prim Care 2012; 39:71-82.

9. Xiang Y, Yang X, Du J. The role of hysterectomy in the therapy of gestational trophoblastic tumor. Zhonghua Zhong Liu Za Zhi 1999; 21:139-41.

10. Xiang Y, Yang X, Zhang L, Song H. Evaluation of emergency surgery in gestational trophoblastic tumours. Zhongguo Yi Xue Ke Xue Yuan Xue Bao 1997;19:369-72.

11. Atala C, Riedemann R, Biotti M, Ramírez F, Paublo M. Invasive mole with uterine rupture. Rev Chil Obstet Ginecol. 1992; 57:356-8.

12. Chandran R, Tham KY, Rose I. Perforating invasive mole masquerading as an ovarian tumour-case report. Med J Malaysia $1991 ; 46: 255-8$.

13. Garza de la Garza R, Livas Rodríguez S, Ploneda González C. Chorioadenoma destruens: presentation of 2 cases. Ginecol Obstet Mex. 1989; 57:139-41. 